\title{
UNFAIR CONTRACT TERMS IN ONLINE CONTRACTS: SPECIAL REFERENCE TO ONLINE BOOKING OF FLIGHT TICKETS
}

\author{
FARIHANA ABDUL RAZAK ${ }^{1^{*}}$, ZUHAIRAH ARIFF ABD GHADAS ${ }^{2}$, FARHANIN A. SUHAIMI ${ }^{2}$ \\ NURZIHAN MOHAMMAD UDIN² \\ ${ }^{1}$ Universiti Teknologi Mara, Kampus Tapah, Perak, Malaysia \\ farihana@uitm.edu.my* (Farihana Abdul Razak) \\ ${ }^{2}$ Faculty of Law and International Relations, Universiti Sultan Zainal Abidin, 21300 Terengganu, Malaysia \\ zuhairahariff@unisza.edu.my (Zuhairah Ariff Abd Ghadas) \\ farhanin@unisza.edu.my (Farhanin A. Suhaimi) \\ nurzihanudin@gmail.com (Nurzihan Mohammad Udin)
}

\begin{abstract}
E-businesses and online transaction have become a norm in today's society. One of the industries that use e-businesses extensively is tourism business and buying online flight ticket is the most common feature of today's way of travelling. In online booking of flight ticket transaction, the standard terms and standard form contracts are generally used to legalize the transactions and consumers have to agree to all the standard terms prior to payment and finalizing the transaction.

Unfair contract terms are terms which may unfairly exclude or limit liabilities in a contract and such terms are legal and binding if agreed and accepted by the contractual parties. It is observed that the application of unfair contract terms is not knowingly or conscientiously accepted by one or some contractual parties as they are normally inserted as standard terms in standard form contracts. It is perceived that with the current practices of standard terms and standard form contracts in online booking of flight tickets, consumers might be a prey of unfair contract terms. This normally occurs when consumers or purchaser agreed to all terms of the airlines operators/companies without properly or vigilantly reading the whole agreements.

This paper analyse the principles, application and effect of unfair contract terms in online booking of flight tickets agreements. For the purpose of discussion in this paper, references are only made to online terms and contract used by airlines companies incorporated in Malaysia.
\end{abstract}

Keywords: Flight Tickets, Online Transaction, Standard Form Contracts, Unfair Terns.

Article Received: 18 October 2020, Revised: 3 November 2020, Accepted: 24 December 2020

\section{Introduction}

As a consumer, people tends to enter into various of contracts almost every day either it has been realised or not and for an example, book a flight ticket, hire a car or a travel agent, will be considered as entering into a contract. Nowadays, customers are exposed to the online transaction business and this kind of business enable customers to use the internet network to purchase goods or book the service online and it is obviously that, customer contract always referring to contract which is normally for personal or domestic use. In addition, it can be simplified that customers are free to enter into any contracts and must take their own interests. In other words, it can be said that most of consumer transactions have shown the consumers have to accept or abide whatever the contractual terms which have been determined by the suppliers or company who is offering the services or goods even there are exclusion clauses and unfair terms or by the "take it or leave it" basis. The customers normally tend to agree and accept the terms and conditions that have been included in the contract because most of the contracts normally insert the terms as standard terms in standard form contracts. Standard form contract is usually can be referred to documentation which has been used by the traders for all transaction of goods and services (Elistina \& Naemah, 2017). Standard form contracts are beneficial to both parties of contract because these kinds of contracts will provide them equal bargaining power, but in certain circumstances, they lead to unfairness among the consumers (Elistina \& Naemah, 2016). Unfair terms are 
referring to the contract clauses that limit the rights of consumers or give unfair advantage to one contracting party under contract law (Adnan Trakic, 2015). Normally, unfair terms can be found in the form of exemption clauses and printed form of the receipts, invoices and other sale documents and almost of the standard form contract which is designed by the traders, there must be expectation of unfair terms that will be found (Naemah Amin, 2013).

The use of unfair terms in consumer contracts have been used widely in practicing the standard form contracts and consumers in Malaysia continue to be frightened with this issue, especially in the context of exemption clauses or exclusion clauses (Alias, S.A.,Ghadas, Z.A.A.., 2012). The application of provision in consumer protection statutes which regards to prohibit contracting out the protection of customers and forbid certain types of unfair terms are still very limited and most of the provisions deal with specific transactions (Naemah Amin, 2013). There is application of the doctrine of inequality of bargaining power or principle of unconscionability that have been introduced by the courts as an attempt to help the weaker party involved in the contract, but at the same time, some cases could not be applied in such judicial intervention (Naemah Amin, 2013).

\section{Online Flight Booking}

With the strong waves of globalization and liberalization across the world, ICT, especially the internet, is regarded to be the most cos-efficient tool to help brick and mortar companies gain bigger markets and the ability to compete with other rival organisations in address attention of the customers to their products, services and information (Mohamed, Intan Salwani \& et al, 1993). The aviation, travel and tourism industry has been rapidly growing and there are series of industry, customer and technology trends converging to redefine operating and business models in the travel ecosystems (World Economic Forum, 2017). Growing demand for travel, particularly in emerging markets, represents a significant opportunity to online travel aggregators (OTAs), meta-search engines and travel service platforms and they challenge inescapably business to adapt their own strategies to growth of their company and services. Travel providers are seeking stronger interactions with customers, while changing operations for better insight of customer preferences and operational performance purpose (World Economic Forum, 2017).

The trends look set to propel the centre stage in shaping travel and tourism in various aspect such as for living travel experience, travellers will experience seamless journeys tailored to their habits and preferences and beneficial to Aviation, Travel and Tourism industry to customize experience data and transaction through online it is one of the way to cut the time of shopping spending. Next aspect is providing better safety and security if there is a collaborative effort towards boosting cybersecurity and protecting the privacy of traveller data (World Economic Forum, 2017). The aviation, travel and tourism industry has been at the forefront of demand, and because of this matter and there have a few platforms in emerging markets to imply the online transaction in business. The travel ecosystem has helped customer expectations for on demand and convenient

\section{Airlines In Malaysia}

There are three types of airlines in Malaysia, namely the commercial, charter and cargo airlines. The commercial airlines are offered by AirAsia, AirAsia X, Firefly, Malindo Air, Malaysia Airlines and MASwings. The charter airlines, are provided by Berjaya Air, Eaglexpress, Layang-layang Aerospace, MHS Aviation, Sabah Air and Weststar Aviation. As for the cargo airlines, the services provider are Gading Sari, MASkargo, Neptune Air and Raya Airways. This paper focus on the commercial airlines where the online booking is extensively used.

\section{Unfair Contract Terms}

The trading environment of trading nowadays are rapidly growth and expand in line with the advancement of technology and it has led to increasing numbers of business practices with 
important ramification of consumer contracts and in consequent, contribute to questioning the legal. The most concern in contract law is the situation where traders are eager to exclude or limit their liability for breach of contract by providing and inserting exemption or exclusion clauses in consumer contracts (Sakina Shaik \& et al, 2012), same with the application of the airline booking of flight tickets. The concern to decrease unfairness is a consequent of inequality of bargaining power as the principle of consumer protection.

The malice of exclusion clauses has been highlighted by many authors such as Beale (1989) which dictates that "most customers faced with the contract containing 'small print' do not know what it contains or understand the effect of the clauses and they do not know what it contains or understand the effect of the clauses, and they do not think it is worthwhile to spend time and money necessary to find out or have the small print explained to them. Instead, they tend to ignore it and shop in terms of price." (Sakina Shaik \& et al, 2012)

In standard form of contracts, exemption clauses or exclusion clauses referring to limit's exemption of a contracting party's liability for certain breaches of the expressed or implied terms of the contract that against the consumers' right. Normally, such clauses can be found at the back of tickets of public transports, on receipts and other types of standard form consumer contracts. The use of such clauses in standard form consumer contracts have been regarded as objectionable by the common law judges which apply the principles to check and control such clauses and they are including the requirement of the clause that must be an integral part of the contractual document (Nik Ramlah Mahmood, 1993).

It is clear that there is a wide range of judicial tools can be used to control the abuse of exemption clauses by apply the contra proferentum rule or the very clear words in every consumer contracts. However, a Malaysian reported case which involved an exemption clause in a standard form consumer contract, none of these judicial tools were used in the Malaysian Supreme. In Malaysian
Airlines System Sdn Bhd v Malini Nathan \& Anor [1986] 1 MLJ 330, the Malaysian Airlines was sued for breach of contract for failing to fly a fourteen year old pupil back to Kuala Lumpur from England. The Supreme Court held that MAS was entitled to rely on the clause after the MAS itself denying liability by relying on Condition 9 under the Conditions of Contract printed on the airline ticket and in addition, MAS was proven that not in breach of contract. Condition 9 under the Conditions of Contract stipulated as follows:

"Carrier undertakes to use its best efforts to carry the passenger and baggage with reasonable dispatch. Times shown in timetables or elsewhere are not guaranteed and form no part of this contract. Carrier may without notice substitute alternate carriers or aircraft, and may alter or omit stopping places shown on the ticket in case of necessity, Schedule are subject to change without notice. Carrier assumes no responsibility for making connections."

Another judicial notice of the fact that one has no bargaining power when dealing with Article 9.2 when purchasing tickets online can be summarize as in Malaysia carriage by Air Act 1974 gives effect to certain conventions relating to carriage by Air known as the "Warsaw Convention at the Hague and in Montreal 1975 Section 6 of Carriage by Air Act 1974. The issue before this Tribunal is whether the claim by the Claimant is frivolous and baseless as alleged by the Respondent and the decision of the Tribunal stated that the Claimant had no bargaining power to negotiate of the terms (Tribunal for Consumer Claims Malaysia, 2011).

\section{Unfair Contract Terms In Airlines Carriage Contracts}

Unfair terms contract normally occurs in unilateral contracts which involves an action that will be undertaken by one person or group alone or in other words, this contract allows only one person to make a promise or agreement and at the same time it will give benefit to one party only. The example of unilateral contract can be shown through the contracts of carriage that highlighted that all other issues of carrier liability to consumers are governed 
by "Conditions of Contract for Carriage." The passenger ticket or air waybill is a contract of carriage, which may incorporate by reference other binding provisions in its Tariffs as long as the ticket or other travel documents provides notice that it incorporates additional terms. These provisions may incorporate arbitrary unilateral terms governing like issues of flight delayed or missed connections (Dempsey, 2014).

Airlines company also use Clickwrap electronic contracts whereby when confronted by a lengthy and incomprehensible contract, the response of many, if not most, consumers is to click 'yes' without reading the contract or giving it careful consideration. This method is a departure from the traditional model of negotiated agreement on terms to the unilateral imposition by suppliers of terms, many of which are unfair.

There are also terms in the online booking of flight tickets which include legal limits on the carrier's liability and other matters like the periods for passengers to file a claim, the rights of carrier to change any terms of the contract and rules regard to reservations, check in times and the items or belongings the carriers refuse to carry (Dempsey, 2014). These provisions also include the Montreal or a Warsaw Conventions for liability of injury, baggage liability and although most carriers enable or promise to compensate passengers for meals and overnight accommodations if necessary, technically airlines are not liable for occurrences caused by the mechanical problems or weather (Dempsey, 2014).

Some of the problematic clauses which should not be allowed in air transport contracts are regards to code share agreements without the consent of the passenger. This clause referring to code share agreements an airline sells tickets for a flight which will be operated by another carrier. Normally all major airlines have one or multiple code share agreements. This code share agreement will confuse the passengers if at the first place, they book tickets in other airlines' website, but rather than flying with the aircraft of the booked airlines, the flight changed its operation with other flight which is not from the original domain airplanes website. This aspect can be seen through the Code Shares under Clause 2.4 of Malaysia Airlines Berhad, General Conditions of Carriage.

Next problem of the air transport is about the use of "no show" clause. According to the Article 6 of Check in and Other Requirements of Carriage carried by AirAsia for AK flights, passenger must present at check in on time and be present at the boarding gate not later than the time specified by the carrier at the time of check in and failing to do so, the fare that has been paid will not be refunded to the passenger.

Other clause that will be considered as unfair is stated that if passengers fail to reconfirm the obligation to reconfirm bookings. Under Article 6 of Reservation, Clause 6.6 in Malaysia Airlines Berhad, general Conditions of Carriage, stated that if passengers fail to reconfirm their reservations, the airlines may decide to cancel the onward or return reservations. This is considered as unfair as it is disproportionate and causes imbalance between the rights and obligations of the parties.

Another clause that shows unfairness is no right to refund in case of force majeure. This term dictates that the passenger does not have the right to refund of the price paid. According to Limitation of liability of Terms and Conditions under Firefly, the airlines will not be liable for any event arising out of any occurrences that beyond their control. This is regards as unfair because it creates a significant imbalance between the rights and obligations among the parties.

Next clause that unfair is exclusion of carrier liability for non-compliance with timetabling, the Article 10 of Malaysia Airlines Berhad, General Conditions of Carriage highlighted that there is no guarantees that the flight will depart and arrive at the times set.

The last but not least is lack transparency, accessibility and clarity of contract terms. This clause is a problem with most of airlines' conditions of carriage with the use of abundant cross-references, overlapping terms and conditions as well as the inaccessibility of terms and conditions offline. Some terms referring to price conditions which indicate of extra fees for excess 
baggage and supplementary, administrative fees and the liability of the company are considered as unfair due to less clarity and precision on the terms provided and lead to consumer detriment in various aspects.

\section{Conclusion}

A research, commissioned by investment specialist Skandia, exposes how easy it is for people booking and paying for goods and services online to click the terms and conditions box without actually reading them in full. Nearly six in $10(58 \%)$ adults said they would rather read an instruction manual or their utility or credit card bill than go through online terms and more than one in $10(12 \%)$ would rather read the phone book. Meanwhile, $43 \%$ of those who don't always read the terms and conditions say they are boring or difficult to understand. But by failing to check the small print they are in the dark about their rights, until something goes wrong. Just over a fifth (21\%) of people surveyed said they had suffered as a result of ticking the terms and conditions box without having done their homework. One in 10 found themselves locked into a longer contract than expected because they signed up without reading the small print, and one in 20 lost monies by not being able to cancel or amend bookings.

Traders have created a free market for smooth flow of their products and at the same time they discharge their liabilities and increase their rights and often discriminate the rights of other parties. The problem occurred by the use of standard form of contract has been haunting the public for a long time and this type of contract often being abused of consumer rights. In the aspect of exclusion of contractual liabilities of traders, standard form contracts and rights of third parties, the law of contract is not the ultimate of consumer rights and there is a need for legal control in order to have better dealings with the consumers. The inconsistencies contained in the legal provision should be reconsidered by the courts and legislators and consumers supposedly not to be burdened by the loopholes of the existing statutory provisions.

\section{REFERENCES}

[1] Alias, S. A., \& Abdul Ghadas, Z. A. (2012). Inequality of bargaining power and the doctrine of unconscionability: Towards substantive fairness in commercial contracts. Australian Journal of Basic and Applied Sciences, 6(11), 331-341.

[2] Amin, N. (2013). Protecting consumers against unfair contract terms in Malaysia: the consumer protection (amendment) act 2010. Malayan Law Journal, 1, 1-11.

[3] Bakar, E. A., \& Amin, N. (2016). CONSUMERS'AWARENESS AND PRACTICES TOWARDS 'EXCLUSION CLAUSE'AND ITS POSITION UNDER MALAYSIAN LAW.

[4] Dempsey. P.S. (2014). Consumer Protection in the Airline Industry. McGill University. p, 4. Retrieved from https://www.mcgill.ca/iasl/files/iasl/aspl63 6_consumer_protection.pdf.

[5] International Labour Organization. (2010). Developments and challenges in the hospitality and tourism sector. Issues paper for discussion at the Global Dialogue Forum for the Hotels, Catering, Tourism Sector, Geneva. Retrieved from http://www.ilo.org/wcmsp5/groups/public/ @ed_norm/@relconf/documents/meetingd ocument/wcms_166938.pdf.

[6] Mahmood, N. R. N. (1993). Unfair terms in Malaysian consumer contracts-The need for increased judicial creativity.

[7] Mohamed Intan Salwani, Govindan Marthandan, Mohd Daud Norzaidi, Siong Choy Chong. (1993). E-commerce usage and business performance in the Malaysian tourism sector: empirical analysis. Information Management \& Computer Security, Vol. 17(2).

[8] Mohd. Faiz Abdullah \& Rozanah Ab. Rahman. (2015). Consent, standard for contracts and empowerment for consumers. Journal of Scientific Research and Development ,2 (14), p.68-73. 
[9] Tho Xin Yi. (2017). China agencies promoting Malaysia. The Star Online. Retrieved from https://www.thestar.com.my/news/nation/2 017/01/13/china-agencies-promoting-msiachinese-nationals-keen-on-adventuretourism/.

[10] Tourism Malaysia and AirAsia to promote tourism. (2017). The Star Online. Retrieved from

https://www.thestar.com.my/business/busi ness-news/2017/05/11/tourism-malaysiaand-airasia-to-promote-tourism/.

[11] Trakic, A. (2015). Statutory protection of Malaysian consumers against unfair contract terms: Has enough been done?. Common Law World Review, 44(3), 203-221.

[12] Tribunal for Consumer Claims Malaysia. (2011). Wilayah Persekutuan Putrajaya.

[13] World Economic Forum. (2017). Digital Transformation Initiative: Aviation, Travel and Tourism Industry. Retrived from https://www.accenture.com/t20170116T08 4449 w $\quad$ /usen/_acnmedia/Accenture/ConversionAssets/WEF/PDF/Accenture-DTIAviation-Travel-and-Tourism-IndustryWhite-Paper.pdf.

[14] Yusoff, S. S. A., Isa, S. M., Aziz, A. A., \& Chin, O. T. (2012). Corporate responsibility via Malaysian contract law: a concern for consumer protection. Pertanika Journal of Social Sciences \& Humanities, 20(1), 227238. 